\title{
Platform dan Pemodelan Kerjasama Multi Agen untuk Layanan Pengiriman Barang
}

\author{
Andrew B. Osmond \\ Institut Teknologi Bandung \\ abosmond@telkomuniversity.ac.id
}

\author{
Suhono Harso Supangkat \\ Institut Teknologi Bandung \\ suhono@stei.itb.ac.id
}

\begin{abstract}
- sistem multi agen sampai saat ini masih banyak diterapkan untuk mensimulasikan berbagai permasalahan di bidang transportasi dan logistik. Teknologi rantai blok juga saat ini mulai banyak diterapkan di berbagai penelitian, walau masih sedikit penerapannya dalam bidang transportasi dan logistik. Di dalam paper ini akan direview paper - paper terkait sistem multi agen dan blockchain untuk bidang transportasi dan logistik. Review ini menggunakan metode Systematic Literature Review (SLR) dengan mendefinisikan pertanyaan penelitian. Setelah mereview 20 paper, maka didapat bahwa pendekatan dalam bidang transportasi dan logistik dengan sistem multi agen sebagian besar digunakan untuk menyelesaikan permasalahan penentuan rute kendaraan dengan memanfaatkan perilaku agen seperti komunikasi, koordinasi, kerjasama, dan perencanaan. Semntara itu, teknologi rantai blok masih sedikit diterapkan dalam bidang transportasi dan logistik. Teknologi rantai blok pada paper yang direview diterapkan dalam komunikasi kendaraan. Kontribusi yang diharapkan dalam paper ini yakni memberikan overview secara umum bagi para peneliti yang ing in melakukan penelitian dalam bidang logistik, khususnya menggunakan pendekatan sistem multi agen dan teknologi rantai blok.
\end{abstract}

Kata Kunci : Transportasi, Logistik, Platform, Multi Agen

Article history:

Received: 20 March 2019 Received in revised form: 29 March 2019 Accepted: 24 April 2019 Available online: April 2019

\section{PERMASALAHAN SAAT INI}

Di kota Bandung, jumlah kendaraan roda dua saat ini sebanyak 1.251.080 unit sedangkan jumlah kendaraan roda empat sebanyak 536.973 unit[1]. Menurut data dari BPS kota Bandung di tahun 2016, jumlah angkot yang ada di seluruh Bandung sebanyak 5.521 unit[2]. Meningkatnya volume kendaraan saat ini yang tidak sebanding dengan kapasitas jalan, menumpuknya kendaraan dari luar kota pada saat akhir pekan, peralihan dari angkutan umum ke angkutan pribadi menjadi sebagian masalah pada pengelolaan transportasi di kota Bandung[3].

Dengan jumlah angkot sebanyak 5.521 unit yang tersebar di 39 trayek, angkot dapat membantu mengurangi kemacetan yang semakin parah di kota Bandung. Akan tetapi, angkot saat ini harus menghadapi persaingan dengan ojek online seperti Gojek dan Grab. Hal ini setidaknya ditunjukkan dari banyaknya jumlah angkot yang dikandangkan karena tidak mampu menutupi beban operasional seiring meningkatnya jumlah ojek online[4]. Selain itu, angkot juga dipandang memiliki masalah terkait stigma budaya yang umum, seperti: ngetem, memaksakan kelebihan muatan penumpang, tarif yang tidak standar, uang kembalian yang tidak sesuai, ugal - ugalan, putar balik, jadwal yang tidak pasti, kurangnya rasa aman dan menaikkan ongkos secara sepihak[5][6]. 
Di sisi lain, agresivitas dan penetrasi e-commerce berbanding lurus dengan jumlah pengguna internet di Indonesia. Sekitar 143 juta orang telah terhubung ke internet, dengan aktifitas yang lebih beragam seperti membeli barang, memesan transportasi, hingga berbisnis dan berkarya[7]. Pembelian barang via e-commerce di Indonesia mencapai Rp 147,7 triliun, meningkat sekitar 41\% dari Rp 74 triliun pada tahun 2015[8]. Tingginya transaksi pembelian di e-commerce ini juga berpengaruh terhadap meningkatnya jumlah pengiriman paket oleh perusahaan kurir, JNE bahkan mengklaim barang yang dikirimkan mencapai 20 juta barang per bulan[9]. Selain pengiriman lewat perusahaan ekspedisi, transaksi e-commerce maupun transaksi lewat media sosial saat ini juga sudah menggunakan jasa armada online seperti Gojek atau Uber. Tahun 2017 tercatat ada 200 ribu penjual online yang menggunakan jasa go-send untuk mengantarkan paket[10]. Sementara marketeers mencatat di tahun 2018, 529 juta makanan dan minuman berhasil dikirim melalui go-food[11].

Dari permasalahan yang dihadapi oleh angkot pada saat ini, akan dikaji usulan penelitian terkait pemanfaatan teknologi untuk mengubah bisnis model angkot dari mengangkut penumpang menjadi barang. Dengan keterbatasan angkot terkait rute atau trayek, maka diperlukan kerjasama dengan moda transportasi yang lain. Permasalahan akademik yang akan diangkat yakni pengembangan model kerjasama dan platform untuk layanan pengiriman barang, yang akan ditinjau dari sisi keilmuan sistem multi agen dan teknologi rantai blok pada bidang transportasi dan logistik.

\section{KONSEP SISTEM MULTI AGEN}

Konsep agen memberikan sesuatu yang baru dalam pemodelan, mencoba mensimulasikan konsep spesifik manusia dalam program komputer. Sudah lebih dari dua puluh tahun penelitian di bidang sistem agen dan multi agen menawarkan hasil yang luar biasa dari sudut pandang teoritis dan praktis. Namun, setelah begitu lama penelitian, masih belum ada konsensus mengenai gagasan dasar seperti "apa itu agen?", "apa itu sistem multiagen?", terminologi yang digunakan, $\mathrm{dsb}[12][13]$.

Beberapa definisi umum dari agen termasuk karakteristiknya sebagai berikut:

1. Agen merupakan entitas yang berjalan terus - menerus dan mandiri dalam suatu lingkungan di mana ada proses lain terjadi dan ada agen lain[14].

2. Agen merupakan entitas yang melakukan penginderaan terhadap lingkungan di sekitarnya dan bereaksi terhadapnya[15].

3. Agen biasanya digunakan untuk merepresentasikan dua entitas orthogonal. Pertama adalah kemampuan agen untuk mengeksekusi rencana secara mandiri, kedua yakni kemampuan untuk melakukan domain oriented reasoning[16].

4. Agen otonom merupakan sistem yang terletak di dalam dan merupakan bagian dari lingkungan, melakukan penginderaan dan bertindak[17].

Salah satu karakteristik agen yakni berinteraksi dengan lingkungan seperti yang disebutkan oleh[13][14][17]. Wooldridge dan Jennings mendefinisikan agen secara lengkap dan komprehensif, yakni bahwa agen merupakan perangkat keras atau perangkat lunak yang memiliki 
karakteristik sebagai berikut: otonom - agen bertindak tanpa campur tangan langsung dari manusia atau yang lain, dan memiliki semacam kontrol atas tindakan dan keadaan internal mereka; kemampuan sosial - agen berkomunikasi dengan agen lain ( dan mungkin manusia ) melalui sejenis bahasa komunikasi agen, reaktif - agen merasakan lingkungan mereka dan merespon dalam waktu yang tepat terhadap perubahan yang terjadi, proaktif - agen tidak hanya bertindak sebagai tanggapan terhadap lingkungan di sekitarnya, mereka juga mampu mengambil inisiatif untuk mencapai tujuan mereka[18].

Beberapa pandangan muncul terhadap apa yang disebut dengan agen. Beberapa peneliti menganggap bahwa agen merupakan entitas tunggal, seperti ditunjukkan oleh Gambar 1, dan ada juga peneliti yang menganggap bahwa agen merupakan entitas yang bertindak secara kolektif dari agen lain. Dari sinilah muncul paradigma baru terhadap sistem multi agen. Menurut[19] sistem multi agen merupakan jaringan agen perangkat lunak yang bersifat loosey coupled yang saling berinteraksi untuk menyelesaikan masalah yang berada di luar kapasitas individu atau pengetahuan masing - masing individu, seperti yang ditunjukkan oleh Gambar 1.

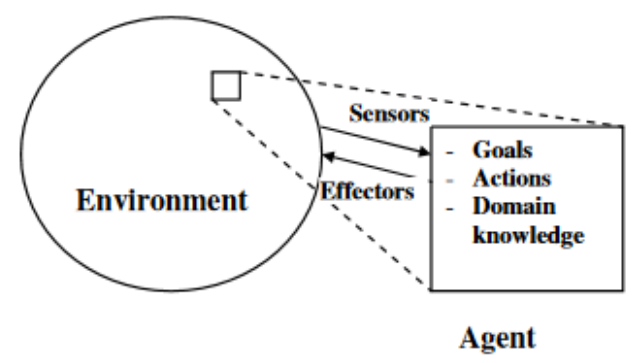

Gambar 1 Framework agen secara umum

Dari sudut pandang teoritis, kebanyakan model agen formal mengambil dari logika modal atau logika pengetahuan dan keyakinan. Model umum yang mungkin untuk logika pengetahuan dan keyakinan awalnya diusulkan oleh Hintikka[22] dan diformulasikan menggunakan semantik Kripke. Cohen dan Levesque[23] mengusulkan bentuk formalism yang awalnya dikenal sebagai teori niat dengan dua sikap dasar, yakni keyakinan dan tujuan. Salah satu model yang sangat berpengaruh saat ini adalah BDI (belief, desire, and intentions)[23]. Level spesifikasi dan desain dari agen cerdas pada sistem multi agen ditunjukkan oleh Gambar 2 berikut 


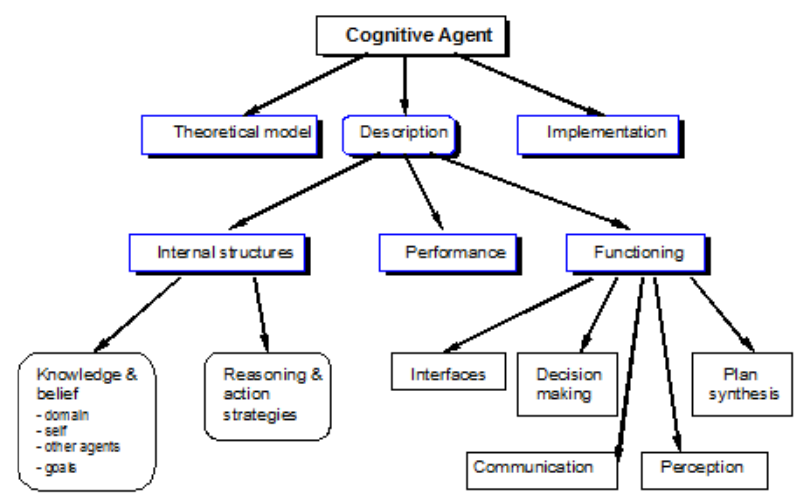

Gambar 2 Level spesifikasi dan desain dari agen cerdas pada sistem multi agen[12]

Peningkatan minat pada penelitian di seputar sistem multi agen dikarenakan banyak keuntungan yang melekat pada sistem, termasuk kemampuan untuk menyelesaikan masalah yang mungkin menjadi sangat besar bagi agen tunggal, serta menyediakan kecepatan dan kehandalan yang meningkat dan mampu mentolerir data dan pengetahuan yang tidak pasti[20]. Beberapa isu yang terkait dengan penyelesaian masalah berbasis agen berada di area koordinasi, negosiasi, dan komunikasi[21].

\section{A.1. Komunikasi}

Interaksi antar agen dilakukan lewat komunikasi, baik yang sederhana maupun yang canggih. Contoh komunikasi sederhana berupa sinyal sederhana dengan terjemahan yang past, seperti yang dilakukan oleh[23]. Bentuk lain dari komunikasi antar agen menggunakan strukur blackboard. Blackboard merupakan sumber daya bersama, biasanya dibagi menjadi beberapa area, sesuai dengan perbedaan jenis pengetahuan atau perbedaan tingkat abstraksi dalam pemecahan masalah, di mana agen dapat membaca atau menulis informasi terkait yang sesuai untuk tindakan mereka. Bentuk komunikasi lain adalah dengan melewatkan pesan (message passing) di antara agen. Contoh interaksi dalam sistem multiagen ditunjukkan oleh Gambar 3. 


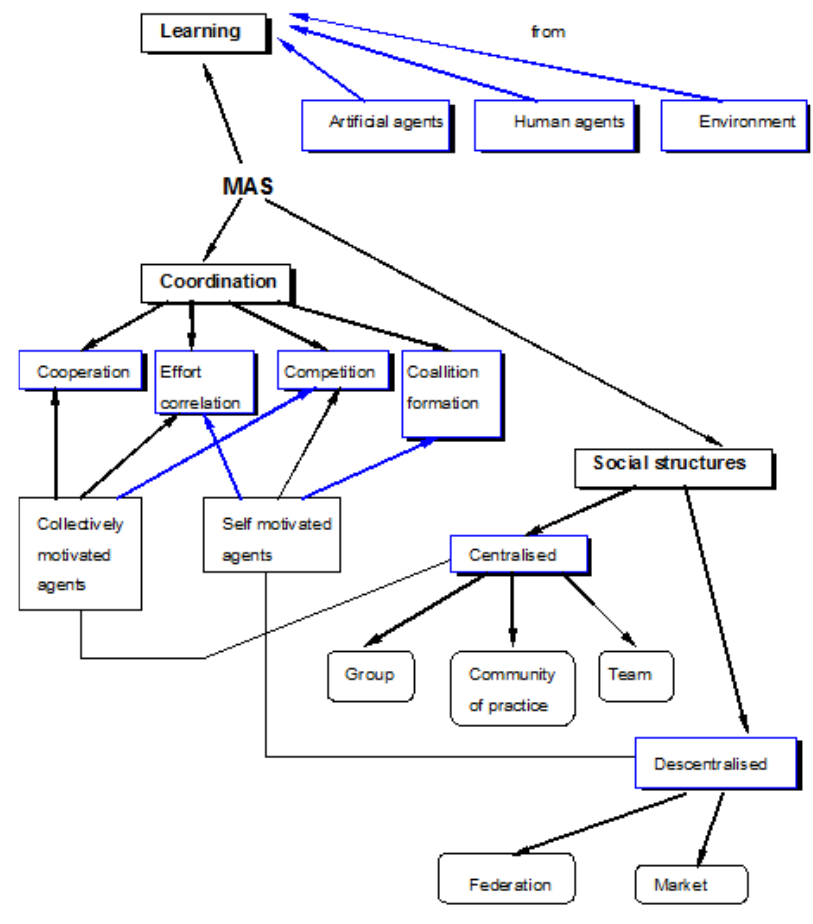

Gambar 3 Interaksi kognitif pada sistem multi agen[12]

\section{A.2. Koordinasi}

Seorang agen ada dan melakukan aktivitasnya dalam masyarakat di mana agen-agen lain keluar. Oleh karena itu, koordinasi antar agen sangat penting untuk mencapai tujuan dan bertindak dengan cara yang koheren. Koordinasi mengimplikasikan pertimbangan tindakan agen-agen lain dalam sistem ketika merencanakan dan mengeksekusi satu tindakan. Koordinasi juga merupak an sarana untuk mencapai perilaku koheren dari keseluruhan sistem. Koordinasi dapat menyiratkan kerjasama untuk mencapai tujuan bersama, tetapi mungkin juga menyiratkan persaingan, ketika agen memiliki tujuan yang berbeda. Dalam kasus ini, koordinasi penting karena agen harus memperhitungkan tindakan pihak lain, misalnya berkompetisi untuk sumber daya tertentu atau menawarkan layanan yang sama.

Banyak model koordinasi dikembangkan untuk pemodelan pemecahan masalah yang didistribusikan secara kooperatif, di mana agen berinteraksi dan bekerja sama untuk mencapai tujuan mereka sendiri dan tujuan bersama sistem secara keseluruhan. Dalam komunitas kooperatif, agen biasanya memiliki kemampuan individu, yang jika digabungkan, akan mengarah pada pemecahan seluruh masalah. Kerja sama diperlukan untuk saling melengkapi, untuk ketergantungan di antara tindakan agen dan dengan kebutuhan untuk memenuhi tujuan bersama. Dalam model kooperatif pemecahan masalah para agen secara kolektif termotivasi atau secara kolektif tertarik, oleh karena itu mereka bekerja untuk mencapai tujuan bersama. Model seperti itu cocok untuk sistem tertutup di mana masyarakat agen adalah priori yang dikenal pada saat desain dan di mana perancang sistem menerapkan protokol interaksi dan strategi untuk setiap agen.

\section{A.3. Negosiasi}


Negosiasi merupakan pusat dari sistem multiagen yang self-interested. Pendekatan teori permainan digunakan oleh[24] untuk menganalisis negosiasi dalam sistem multi-agen. Model negosiasi diusulkan oleh di mana agen membuat usulan dan bantahan, alasan untuk saling melengkapi dengan kerja sama. Protokol negosiasi hirarkis, dikembangkan, yang memungkinkan agen secara fleksibel menemukan dan memecahkan kemungkinan konflik. [25][26] menggunakan strategi negosiasi untuk alokasi sumber daya dan distribusi tugas.

\section{KONSEP TEKNOLOGI RANTAI BLOK}

Blockchain merupakan sebuah buku besar terdistribusi (distributed ledger) terbuka yang dapat mencatat transaksi dari partisipan di dalam jaringan. Rantai blok diamankan menggunakan kriptografi seperti fungsi hash, tanda tangan digital, dan enkripisi [27]. Fungsi hash digunakan pada blok dan membentuk identifier blok yang unik yang disimpan pada blok subsequent. Untuk memverifikasi sebuah blok maka cukup dibandingkan menjalankan fungsi hash dari blok dan membandingkannya dengan hasil yang ada pada blok subsequent. Rantai blok akan direplikasi dan didistribusikan ke setiap partisipan secara desentralisasi. Upaya yang dilakukan untuk merusak informasi yang disimpan dalam blok akan diketahui oleh semua partisipan sehingga menjamin ketetapan yang ada pada ledger. Ilustrasi rantai blok ditunjukkan oleh Gambar 4 berikut:

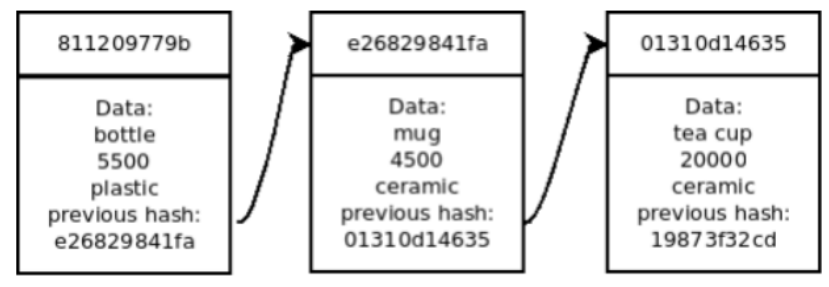

Gambar 4 Ilutrasi rantai blok

Mekanisme yang dipakai oleh rantai blok untuk memastikan keamanan dari rantai blok tetap terjaga ada beberapa[28], yaitu:

1. Tanda tangan digital

Tanda tangan digital yang dipakai pada rantai blok menggunakan fungsi hash yang sifatnya satu arah. Karena sifatnya satu arah, maka nilai hash ini tidak dapat dikembalikan ke bentuk semula. Apabila baris informasi yang ditandatangani berubah nila inya, maka nilai hashnya juga akan beurbah dan ini akan diketahui oleh semua partisipan yang tergabung dalam jaringan.

2. Proof-of-work

Mekanisme ini bertujuan untuk memperlambat pembuatan blok baru supaya proses perhitungan proof-of-work dapat terjaga. Contoh : blockchain yang digunakan oleh bitcoin memerlukan waktu 10 menit untuk melakukan mekanisme proof-of-work saat sebuah blok baru ditambahkan.

3. Peer-to-peer

Merupakan sebuah mekanisme untuk mendistribusikan catatan transaksi kepada orangorang atau user yang tergabung dalam jaringan peer-to-peer blockchain. Pada intinya, 
mekanisme ini akan bekerja seperti berikut ini; seseorang yang baru bergabung dengan jaringa peer-to-peer blockchain akan memperoleh salinan lengkap transaksi yang terjadi di dalam jaringan tersebut. Dan bila suatu saat terjadi sebuah transaksi atau penambahan block baru maka informasi mengenai block baru tersebut akan dikirimkan ke semua node/user yang ada dan diverifikasi. Setelah proses verifikasi selesai dan block baru tersebut dinyatakan valid, maka block baru tersebut akan dicatatkan kedalam blockchain masing-masing user.

\section{METODOLOGI REVIEW}

Untuk mendapatkan pemahaman yang menyeluruh terhadap peluang penelitian yang terkait dengan teknologi rantai blok dan sistem multi agen dalam bidang transportasi, maka dilakukan studi terhadap literatur yang relevan. Pertama disusun Goal-Question-Metric dengan pertanyaan umum "Apa tantangan yang membutuhkan sistem multi agen dan rantai blok dalam bidang transportasi?". Selanjutnya pertanyaan umum tersebut akan dibagi lagi menjadi pertanyaan penelitian (PP) yang lebih detail sebagai berikut:

\begin{tabular}{|l|l|}
\hline PP1 & $\begin{array}{l}\text { Bagaimana sistem multi agen, teknologi rantai blok, maupun kombinasi } \\
\text { dari sistem multi agen dan teknologi rantai blok berkembang selama } \\
\text { bertahun - tahun? }\end{array}$ \\
\hline PP2 & $\begin{array}{l}\text { Apa motivasi yang mendukung penggunaan sistem multi agen, teknologi } \\
\text { rantai blok dalam bidang transportasi dan logistik? }\end{array}$ \\
\hline PP3 & $\begin{array}{l}\text { Apa domain aplikasi yang yang menggunakan sistem multi agen, } \\
\text { teknologi rantai blok dalam bidang transportasi dan logistik? }\end{array}$ \\
\hline PP4 & $\begin{array}{l}\text { Apa kelebihan dan kekurangan yang disiratkan dari teknologi tersebut? } \\
\text { Apa arahan dan tantangan penelitian di masa mendatang yang terkait } \\
\text { transportasi dan logistik? }\end{array}$ \\
\hline PP5
\end{tabular}

Untuk mendapatkan hasil yang semi akurat, dilakukan pencarian dengan kata kunci multi agent transportation, blockchain transportation, blockchain logistics, dan multi agent logistics. Hasil pencarian awal menghasilkan 368 paper, kemudian diterapkan kriteria inklusi sehingga didapat hasil akhir 20 paper.

Tabel 1. Kriteria Inklusi

\section{Kriteria Inklusi}

- Membahas seputar transportasi, logistik menggunakan pendekatan sistem multi agen atau teknologi rantai blok.

- Artikel berupa artikel review, artikel riset, dan artikel data.

- Artikel bertujuan untuk mereview, mensimulasikan, membuat purwarupa, atau mensimulasikan sistem multi agen dan teknologi rantai blok untuk transportasi dan logistik. 


\section{HASIL REVIEW}

Hasil review ditunjukkan oleh Tabel 2 berikut ini.

Tabel 2. Domain dan Aplikasi sistem multi agen dan blockchain dalam transportasi

\begin{tabular}{|c|c|c|}
\hline Domain & Aplikasi & Referensi \\
\hline \multirow{3}{*}{$\begin{array}{l}\text { Routing dan } \\
\text { penjadwalan }\end{array}$} & $\begin{array}{l}\text { - simulasi sistem multi agen untuk menyelesaikan } \\
\text { VRPTW, VRPTW-F }\end{array}$ & \multirow{3}{*}{$\begin{array}{l}{[32],[33],[35],} \\
{[36],[38],[39],} \\
{[40],[47],[37]}\end{array}$} \\
\hline & - simulasi konsolidasi pengangkutan barang. & \\
\hline & - simulasi kebencanaan untuk logistik dalam kota & \\
\hline Komunikasi & $\begin{array}{l}\text { - sistem komunikasi kendaraan berbasis rantai } \\
\text { blok }\end{array}$ & {$[30]$} \\
\hline $\begin{array}{l}\text { Perencanaan, } \\
\text { kolaborasi, } \\
\text { kerjasama }\end{array}$ & $\begin{array}{l}\text { - } \text { sistem pendukung keputusan untuk perencanaan } \\
\text { pengiriman. } \\
\text { - simulasi konsolidasi pengangkutan barang. } \\
\text { - perencanaan muatan truk barang secara dinamis }\end{array}$ & {$[41],[44]$} \\
\hline \multirow{4}{*}{ Platform } & - smart connected logistics & \multirow{4}{*}{$\begin{array}{l}{[31],[43],[45],} \\
{[46],[48]}\end{array}$} \\
\hline & - layanan reservasi pengiriman barang & \\
\hline & - layanan lelang jasa pengiriman barang & \\
\hline & - layanan trip planner information system* & \\
\hline Rantai pasok & $\begin{array}{l}\text { - simulasi kolaborasi pada sistem rantai pasok } \\
\text { barang }\end{array}$ & {$[29],[34]$} \\
\hline Framework agent & $\begin{array}{l}\text { - framework berbasis agent untuk logistik dalam } \\
\text { kota }\end{array}$ & {$[42]$} \\
\hline
\end{tabular}

- Bagaimana sistem multi agen, teknologi rantai blok, maupun kombinasi dari sistem multi agen dan teknologi rantai blok berkembang selama bertahun - tahun?

Sistem multi agen yang telah lama muncul masih digunakan hingga saat ini. Dari pencarian yang dilakukan ada 18 paper terkait sistem multi agen dalam bidang transportasi serta logistik. Untuk teknologi rantai blok hanya ada 2 paper[29][30] yang terkait dengan transportasi dan logistik di tahun 2019 ini. Penelitian dalam bidang transportasi dan logistik menggunakan sistem multi agen rata - rata berasal dari Eropa, Jepang, dan Amerika. Sedangkan penelitian mengenai teknologi rantai blok berasal dari Amerika dan Korea Selatan.

- Apa motivasi yang mendukung penggunaan sistem multi agen, teknologi rantai blok dalam bidang transportasi dan logistik?

Pada paper - paper yang telah direview, sebagian besar paper sistem multi agen yang terkait berfokus pada topik routing dan penjadwalan[32][33][35][36][38][39][40][47]. Lalu ada manajemen rantai pasok[34], platform layanan [43][45][46], framework agent[42], serta 
kolaborasi dan perencanaan[41][44]. Sementara untuk rantai blok, topik penelitian berfokus pada manajemen rantai pasok[29] dan komunikasi antar kendaraan[30].

- Apa domain aplikasi yang yang menggunakan sistem multi agen, teknologi rantai blok dalam bidang transportasi dan logistik?

Domain dan aplikasi yang menggunakan sistem multi agen, teknologi rantai blok ditunjukkan oleh Tabel X. Lebih dari 50\% penelitian terkait sistem multi agen dan teknologi rantai blok dalam bidang transportasi dan logistik masih berupa simulasi. Hanya satu paper[45] yang membuat purwarupa, dan ada satu paper[47] yang mengevaluasi permasalahan logistik dalam kota dan metodenya.

\section{- Apa kelebihan dan kekurangan dari teknologi tersebut?}

Pendekatan simulasi sebuah sistem dengan multi agen sudah diterapkan sejak lama. Pencarian di laman IEEExplore menunjukkan bahwa penelitian terkait multi agen sudah ada sejak tahun 1988 dengan fokus pada bidang kecerdasan buatan, robotika, dan sistem otonom. Baru pada tahun 90 an mulai muncul penelitian terkait sistem multi agen dalam bidang transportasi atau logistik, Sistem multi agen banyak digunakan untuk mensimulasikan berbagai solusi untuk menyelesaikan permasalahan penentuan rute kendaraan (VRP) dikarenakan agen dapat menjalankan perilakunya sendiri sehingga sistem dapat tidak secara langsung diuji pada kondisi yang nyata.

Teknologi rantai blok sendiri digunakan untuk komunikasi kendaraan seperti yang disampaikan pada paper[30]. Paper[30] mengajukan sistem komunikasi antar kendaraan berbasis teknologi rantai blok sehingga masing - masing kendaraan dapat bertukar informasi mengenai kondisi lalu lintas yang ada. Kelemahan dari teknologi rantai blok pada transportasi kendaraan meliputi jumlah transaksi (banyaknya informasi yang di-broadcast), semakin banyak blok yang ditambahkan ke dalam rantai semakin lama pula waktu yang dibutuhkan untuk melakukan mining terhadap informasi yang disebarkan.

- Apa arahan dan tantangan penelitian di masa mendatang yang terkait dengan sistem multi agen dan teknologi rantai blok dalam bidang transportasi dan logistik?

Konsep mobility as a service saat ini mulai banyak diimplementasikan di berbagai negara. Penelitian terkait konsep mobility as a service salah satunya berupa traveler information system (TIS) seperti yang diteliti oleh paper[48]. TIS membantu para pengguna untuk menentukan pilihan moda transportasi untuk bepergian dengan menggabungkan moda transportasi publik dan pribadi. Konsep TIS dapat diadopsi ke arah logistik pengiriman barang dengan memanfaatkan berbagai macam moda transportasi dengan kelebihan dan kekurangannya masing - masing. Teknologi rantai blok juga dapat dikembangkan untuk layanan logistik. Teknologi rantai blok memang mempunyai beberapa kekurangan diantaranya waktu komputasi yang dibutuhkan untuk melakukan mining data dalam blok, semakin besar ukuran blok maka waktu yang dibutuhkan untuk melakukan mining juga semakin besar. Paper[30] menawarkan solusi dengan memecah rantai blok menjadi beberapa rantai secara parallel. Penerapan blokchain untuk transportasi sejauh ini ditunjukkan oleh 
paper[30] sehingga masih mungkin untuk diterapkan pada logistik untuk pembayaran maupun pelacakan lokasi. Pendekatan sistem multi agen masih cocok digunakan untuk mensimulasikan berbagai bentuk pemodelan: perencanaan, kerjasama, serta kolaborasi untuk berbagai studi kasus di bidang pengiriman barang.

\section{KESIMPULAN}

Konsep multi agen walaupun sudah lama tetapi masih saat ini diterapkan dalam berbagai macam simulasi. Dalam transportasi dan logistik, sistem multi agen banyak digunakan untuk mensimulasikan solusi untuk menyelesaikan permasalahan penentuan rute kendaraan (vehicle routing problem) dengan mengadopsi perilaku kerjasama, negosiasi, maupun komunikasi. Sementara itu penelitian mengenai penerapan teknologi rantai blok dalam logistik maupun transportasi masih sedikit ditemukan. Rantai blok di dalam paper yang direview digunakan sebagai sarana komunikasi antar kendaraan, sementara masih banyak aspek dari rantai blok yang dapat diimplementasikan dalam berbagai macam studi kasus terkait pengiriman barang.

\section{DAFTAR PUSTAKA}

[1] Andriyawan, Dea, 2018, Pertumbuhan Kendaraan Di Bandung 11\% Per Tahun[Online], http://bandung.bisnis.com/read/20181002/82444/580942/pertumbuhan-kendaraan-dibandung-11-per-tahun, diakses tanggal 15 Februari 2019.

[2] -, Bandung Dalam Angka 2018 [Online], tersedia di: https://bandungkota.bps.go.id/publication/2018/08/16/a2782ae62042b1aee91fb4bc/kota bandung-dalam-angka-2018.html, diakses tanggal 15 Februari 2019.

[3] Huda, Nida N, 2013, Talkshow Gempar 2013: Ungkap Permasalahan Transportasi Bandung [Online], tersedia di: https://www.itb.ac.id/news/3823.xhtml, diakses 15 Februari 2019.

[4] Luciana, Anissa, 2017, 50 Persen Angkot Bandung Dikandangkan, karena Angkutan Online? [Online], tersedia di: https://bisnis.tempo.co/read/1024380/50-persen-angkotbandung-dikandangkan-karena-angkutan-online, diakses tanggal 15 Februari 2019.

[5] Pertiwi, Putri Indah, dkk, 2010, BUDAYA SOPIR ANGKUTAN KOTA DI KOTA BANDUNG [online], tersedia di: https://antroitb.wordpress.com/2010/01/05/kelompok10b-budaya-sopir-angkot-di-kota-bandung/, diakses tanggal 15 Februari 2019.

[6] Mutiah, Dinny, 2017, Makin Ditinggalkan, Perlukah Angkot di Bandung Dipertahankan? [Online], tersedia di : https://www.liputan6.com/regional/read/2909825/makinditinggalkan-perlukah-angkot-di-bandung-dipertahankan, diakses tanggal 15 Februari 2019.

[7] Bohang, Fatimah K, 2018, Berapa Jumlah Pengguna Internet Indonesia? [Online], tersedia di : https://tekno.kompas.com/read/2018/02/22/16453177/berapa-jumlah-penggunainternet-indonesia, diakses tanggal 15 Februari 2019.

[8] Iskandar, 2018, Orang Indonesia Habiskan Rp 146 Triliun untuk Belanja Online [Online], tersedia di : https://www.liputan6.com/tekno/read/3326217/orang-indonesia-habiskan-rp146-triliun-untuk-belanja-online, diakses tanggal 15 Februari 2019.

[9] Pratama, Akhdi M, 2018, Dampak E-Commerce, JNE Kirim 20 Juta Barang per Bulan [Online], tersedia di : https://ekonomi.kompas.com/read/2018/11/26/191256126/dampak e-commerce-jne-kirim-20-juta-barang-per-bulan., diakses tanggal 16 Februari 2019. 
[10] Luciana, Anisa, 2017, Gojek: 200 Ribu Penjual Online Gunakan Go-Send untuk Antar Paket [Online], tersedia di : https://bisnis.tempo.co/read/1040227/gojek-200-ribu-penjualonline-gunakan-go-send-untuk-antar-paket, diakses tanggal 18 Februari 2019.

[11] Triwijanarko, Ramadhan, 2019, Apa Saja Yang Go-Jek Capai Selama Tahun 2018 Lalu? [Online], tersedia di : http://marketeers.com/apa-saja-yang-gojek-capai-selama-tahun2018-lalu, diakses tanggal 18 Februari 2019.

[12] Florea, Adina Magda, 1998, Introduction to Multi-Agent Systems, International Summer School on Multi-Agent Systems.

[13] Glavic, Mevludin, 2006, Agents and Multi-Agent Systems : A Short Introduction for Power Engineers, a technical report.

[14] Shoham,Y. Agent-oriented programming. Artificial Intelligence, Vol. 60, 1993. p.51-92.

[15] Russell,S.J. Rationality and intelligence. Artificial Intelligence, Vol. 94, 1997. p.57-77.

[16] http://www.crystaliz.com/logicware/mubot.html

[17] Franklin,S. and A. Gasser. Is it an agent, or just a program?: A taxonomy for a utonomous agents. In Muller, Wooldridge, and Jennings, eds. Intelligent Agents III. Agent Theories, Architectures, and Languages. Springer Verlag, 1997. p.21-35.

[18] Wooldridge,M and N. R. Jennings. Agent theories, architectures, and languages. In Wooldridge and Jennings, eds. Intelligent Agents, Springer Verlag, 1995. p.1-22.

[19] Durfee, E. H., \& Lesser, V. (1989). Negotiating task decomposition and allocation using partial global planning. In L. Gasser, \& M. Huhns, Distributed artificial intelligence (Volume II) (pp. 229-244). London/- San Mateo, CA: Pitman Publishing/Morgan Kaufmann, 229-244.

[20] Park, Sooyong \& Sugumaran, Vijayan. (2005). Designing multi-agent systems: A framework and application. Expert Systems with Applications. 28. 259-271. 10.1016/j.eswa.2004.10.006.

[21] S. Nwana, Hyacinth. (1996). Software agents: An overview. The Knowledge Engineering Review. 11. 10.1017/S026988890000789X.

[22] Hintikka,J. Knowledge and Belief. Cornell University Press, 1962.

[23] Rao,A.S. and M.P. Georgeff. Modeling rational agents within a BDI-architecture. In R. Fikes and E. sandewall, eds., Proc. of Knowledge Representation and Reasoning'91, Morgan Kaufman, 1991. p.473-484.

[24] Zlotkin, G. and J.S. Rosenschein. Negotiation and task sharing among autonomous agents in cooperative domains. In Proc of the 11 th IJCAI, Detroit, USA, 1989.

[25] Kraus,S. An overview of incentive contracting. Artificial Intelligence 83, 1996, 297-346.

[26] Kraus,S. Negotiation and cooperation in multi-agent environments. Artificial Intelligence 94 (1-2), 1997, 79-97.

[27] Nakamoto, S.: Bitcoin: A peer-to-peer electronic cash system (2008)

[28] Yulianton, H., Mulyani, S., 2018, Implementasi Blockchain Sederhana.

[29] Queiroz, M. M., \& Fosso Wamba, S. (2019). Blockchain adoption challenges in supply chain: An empirical investigation of the main drivers in India and the USA. International Journal of Information Management, 46(September 2018), 70-82.

[30] Queiroz, M. M., \& Fosso Wamba, S. (2019). Blockchain adoption challenges in supply chain: An empirical investigation of the main drivers in India and the USA. International Journal of Information Management, 46(September 2018), 70-82. 
[31] Jabeur, N., Al-Belushi, T., Mbarki, M., \& Gharrad, H. (2017). Toward Leveraging Smart Logistics Collaboration with a Multi-Agent System Based Solution. Procedia Computer Science, 109(2016), 672-679.

[32] Teo, J. S. E., Taniguchi, E., \& Qureshi, A. G. (2012). Evaluating City Logistics Measure in E-Commerce with Multiagent Systems. Procedia - Social and Behavioral Sciences, 39, 349359. https://doi.org/10.1016/j.sbspro.2012.03.113

[33] Tamagawa, D., Taniguchi, E., \& Yamada, T. (2010). Evaluating city logistics measures using a multi-agent model. Procedia - Social and Behavioral Sciences, 2(3), 6002-6012. https://doi.org/10.1016/j.sbspro.2010.04.014

[34] Khayyat, M., \& Awasthi, A. (2016). An Intelligent Multi-agent Based Model for Collaborative Logistics Systems. Transportation Research Procedia, 12(June 2015), 325338. https://doi.org/10.1016/j.trpro.2016.02.069

[35] Baykasoglu, A., \& Kaplanoglu, V. (2011). A multi-agent approach to load consolidation in transportation. Advances in Engineering Software, 42(7), 477-490. https://doi.org/10.1016/j.advengsoft.2011.03.017

[36] Sprenger, R., \& Mönch, L. (2014). A decision support system for cooperative transportation planning: Design, implementation, and performance assessment. Expert Systems with Applications, 41(11), 5125-5138. https://doi.org/10.1016/j.eswa.2014.02.032

[37] Schroeder, S., Zilske, M., Liedtke, G., \& Nagel, K. (2012). Towards a Multi-Agent Logistics and Commercial Transport Model: The Transport Service Provider's View. Procedia Social and Behavioral Sciences, 39, 649-663. https://doi.org/10.1016/j.sbspro.2012.03.137

[38] Schroeder, S., Zilske, M., Liedtke, G., \& Nagel, K. (2012). Towards a Multi-Agent Logistics and Commercial Transport Model: The Transport Service Provider's View. Procedia Social and Behavioral Sciences, 39, 649-663. https://doi.org/10.1016/j.sbspro.2012.03.137

[39] De Oliveira, L. K., Lessa, D. A., Oliveira, E., \& Gregório Calazans, B. F. (2017). Multiagent modelling approach for evaluating the city logistics dynamic in a vulnerability situation: An exploratory study in Belo Horizonte (Brazil). Transportation Research Procedia, 25, 1046-1060. https://doi.org/10.1016/j.trpro.2017.05.478

[40] Baykasollu, A., \& Kaplanotlu, V. (2015). An application oriented multi-agent based approach to dynamic load/truck planning. Expert Systems with Applications, 42(15-16), 6008-6025. https://doi.org/10.1016/j.eswa.2015.04.011

[41] Feng, F., Pang, Y., Lodewijks, G., \& Li, W. (2017). Collaborative framework of an intelligent agent system for efficient logistics transport planning. Computers and Industrial Engineering, 112, 551-567. https://doi.org/10.1016/j.cie.2016.12.044

[42] Anand, N., Duin, J. H. R. Van, \& Tavasszy, L. (2016). Framework for Modelling Multistakeholder City Logistics Domain Using the Agent based Modelling Approach. Transportation Research Procedia, 16(March), 4-15. https://doi.org/10.1016/j.trpro.2016.11.002

[43] Gregor, T., Krajčovič, M., \& Więcek, D. (2017). Smart Connected Logistics. Procedia Engineering, 192, 265-270. https://doi.org/10.1016/j.proeng.2017.06.046

[44] Memon, M. A., \& Archimede, B. (2013). A multi-agent distributed framework for collaborative transportation planning. IFAC Proceedings Volumes (IFAC-PapersOnline) (Vol. 46). IFAC. https://doi.org/10.3182/20130619-3-RU-3018.00303

[45] Patier, D., David, B., Chalon, R., \& Deslandres, V. (2014). A New Concept for Urban Logistics Delivery Area Booking. Procedia - Social and Behavioral Sciences, 125, 99-110. https://doi.org/10.1016/j.sbspro.2014.01.1459 
[46] Robu, V., Noot, H., La Poutré, H., \& Van Schijndel, W. J. (2011). A multi-agent platform for auction-based allocation of loads in transportation logistics. Expert Systems with Applications, 38(4), 3483-3491. https://doi.org/10.1016/j.eswa.2010.08.136

[47] Taniguchi, E., Thompson, R. G., \& Yamada, T. (2012). Emerging Techniques for Enhancing the Practical Application of City Logistics Models. Procedia - Social and Behavioral Sciences, 39, 3-18. https://doi.org/10.1016/j.sbspro.2012.03.087

[48] Dotoli, M., Zgaya, H., Russo, C., \& Hammadi, S. (2017). A Multi-Agent Advanced Traveler Information System for Optimal Trip Planning in a Co-Modal Framework. IEEE Transactions on Intelligent Transportation Systems, 18(9), 2397-2412. https://doi.org/10.1109/TITS.2016.2645278 